\title{
Determinants of Nutritional Status of School Children
}

\author{
Maj R Mukherjee*, Lt Col S Chaturvedi', Col R Bhalwar*
}

\begin{abstract}
Background : A cross sectional study was carried out to determine the nutritional status of school children in Army School, Pune. Methods: Anthropometric survey of 760 school children was carried out and compared against the NCHS/WHO reference standards to determine their nutritional status. Associations of nutritional status with socio-economic status, education status of parents, mothers working status and family size were determined.

Result: The prevalence of stunting was $\mathbf{1 3 . 8 1 \%}$, wasting $\mathbf{6 . 7 1 \%}$ and under nutrition $\mathbf{9 . 8 7 \%}$. Mothers' educational level, wasting, socio economic status and family size were significantly associated with the nutritional status of the child.

Conclusion: Maternal educational status, socio-economic status and family size are important determinants of nutritional status of school children.
\end{abstract}

MJAFI 2008; $64: 227-231$

Key Words : Nutritional status; Maternal education

\section{Introduction}

$\mathrm{M}$ alnutrition contributes directly or indirectly to more than $60 \%$ of 10 million child deaths each year [1]. In the developing world, $43 \%$ of the children are stunted and $9 \%$ are wasted [2]. In India, the National Family Health Survey I \& II reported that both chronic and acute undernutrition was high in many states [3]. This results in decreased scholastic performances, lower IQ levels, poor psychosocial development, decreased cognitive functions and reduced adult size leading to decreased economic productivity [4]. The present study was carried out to determine the nutritional status of children studying in Army School at Pune.

\section{Material and Methods}

A cross sectional study was carried out at the Army School, Pune, which is a coeducational school with classes from nursery to class XII with a total strength of around 2100 children. Each class had five sections and children were randomly allocated to different sections irrespective of sex, socioeconomic status or academic performance. The study was carried out on children in the age group of 5-11 years in class I to VI. Sample size was calculated taking alpha error as $5 \%, \mathrm{p}=0.5$, expected deviation as $4 \%$. As per above assumptions the sample size calculated was 600 . Around 1200 children were in the age group of 5-11 years. These were predominantly children in classes I to VI. Three sections were chosen randomly for each class and all children in these three sections were selected into the study. The total number children were 760.

Each child's height and weight was measured in the metric system, using standardized technique recommended by Jelliffe [5]. Body weight was recorded with the help of a electronic weighing machine to the nearest 0.1 kilogram with their uniforms without any footwear and one kilogram was deducted for weight of uniform. Height was measured with the help of anthropometric rod in the Frankfurt plane to the nearest $0.1 \mathrm{~cm}$. Data was analysed using Epi Info 6 software of CDC, Atlanta, USA. Height for age (Stunted), Weight for height (Wasted), and Weight for age (Under weight) for each child was calculated and compared with the WHO/NCHS standard. Cut off point values between $\pm 2 \mathrm{SD}$ were considered normal $[6,7]$.

For assessing socioeconomic status, subjects were divided into three groups, viz. children whose parents were Officers, Junior Commissioned Officers (JCOs) and Other Ranks (ORs) as in the Armed Forces most amenities like housing and income is clearly demarcated between these three groups. If both the parents were employed in the defence services, then child was classified on the basis of the higher ranked parent.

Age of the child was determined using the school records. Mother and father's education level was classified into five groups i.e. Illiterate (no formal education), Primary (completed class V), Middle School (completed class VIII), High School (completed class X), Intermediate (completed class XII) and Graduate and beyond (completed graduation or beyond). Any mother who was gainfully employed, with financial remunerations and was working for at least the past 12 months outside the house, was considered to be a working mother.

Results

The age and sex distribution of children is given in Table

*Officer Commanding, $136 \mathrm{SHO}(\mathrm{L}), 903136, \mathrm{C} / \mathrm{o} 56$ APO. ${ }^{+}$Ex-Associate Professor, "Professor \& Head (Department of Community Medicine), Armed Forces, Medical College, Pune 411040.

Received : 11.08.2006; Accepted : 19.03.2007_E-mail : reemamuk_afmc@yahoo.co.in 
1. Of the 760 children studied, $359(47.23 \%)$ were females and $401(52.77 \%)$ males, with a sex ratio of 895 females per 1000 males. Of these 760 children, $426(56.07 \%)$ belonged to the ORs category, $176(23.15 \%)$ were from the JCOs category and $158(20.78 \%)$ from Officer's category. 262 (34.49\%) children had mothers who were graduates and beyond, $59(7.76 \%)$ mothers were educated till primary level, $96(12.63 \%)$ till middle school, 180 (23.68\%) till high school and $163(21.44 \%)$ had studied till intermediate school. None of the mothers were illiterates. On comparing the homogenicity of distribution of girls and boys according to maternal education status it was found that the boys and girls were homogeneously distributed $\left(\chi^{2}=1.51, \mathrm{df}=4, \mathrm{p}>0.05\right)$. Majority of the mothers $682(89.74 \%)$ were housewives. The girls and boys were homogenously distributed as per the working status of the mothers $(\mathrm{p}=0.83)$. Of the 760 children, $308(40.55 \%)$ had fathers who were graduates or beyond, 223 (29.34\%) had studied up to intermediate school, $139(18.28 \%)$ had studied upto high school, 139(18.28\%) up to middle school and 44 $(5.78 \%)$ up to primary school. None of the fathers were illiterate. The boys and girls were homogeneously distributed with respect to fathers' education status $(p=0.32)$. On analyzing the data according to family size $159(70.26 \%)$ children came from families which had three members, and 67 $(8.82 \%)$ children were from families with more than five members. The girls and boys were homogeneously distributed with respect to the family size $(\mathrm{p}=0.067)$.

Table 2 shows the mean weights of boys and girls of the study group. The mean weight increased from $18.4 \mathrm{~kg}$ and $18.0 \mathrm{~kg}$ for boys and girls respectively in the $5+$ age group to

Table 1

Distribution of children by age and sex

\begin{tabular}{lllr}
$\begin{array}{l}\text { Age group } \\
\text { (years) }\end{array}$ & Females $(\%)$ & Males $(\%)$ & Total $(\%)$ \\
\hline $5+$ & $25(48.07)$ & $27(51.93)$ & $52(100)$ \\
$6+$ & $66(49.62)$ & $67(50.38)$ & $133(100)$ \\
$7+$ & $68(51.90)$ & $63(48.10)$ & $131(100)$ \\
$8+$ & $46(36.22)$ & $81(63.78)$ & $127(100)$ \\
$9+$ & $61(43.57)$ & $79(56.43)$ & $140(100)$ \\
$10+$ & $51(49.03)$ & $53(50.97)$ & $104(100)$ \\
$11+$ & $42(57.53)$ & $31(42.47)$ & $73(100)$ \\
Total & $359(47.23)$ & $401(52.77)$ & $760(100)$
\end{tabular}

$34.5 \mathrm{~kg}$ and $35.7 \mathrm{~kg}$ respectively in the $11+$ age group. The mean weight of boys was more than the girls till eight years of age, thereafter the girls weighed more. However there was no statistically significant difference in the mean weights of the boys and girls in any of the age groups. On comparison with the NCHS/WHO standard the mean weight of boys and girls of the present study was found to be lower in all age groups. Table 3 shows the mean height of boys and girls. The mean height of girls was lower than that of the boys till eight years of age, but thereafter the girls were taller than the boys. This difference in the heights of the boys and girls was not significant in any age group. The mean height of boys and girls of the study group was lower than the WHO/NCHS standards in all age groups.

As per the WHO/NCHS standards, 105 (13.81\%) children out of the total 760 children were stunted, with 21 (2.76\%) children showing severe grade of stunting (Table 4). Among the girls, $45(12.53 \%)$ were stunted as compared to $60(14.96 \%)$ boys $(\mathrm{p}=0.33)$. The boys and girls were homogeneously distributed with respect to grades of stunting, $(\mathrm{p}=0.54)$. Wasting was present in $51(6.71 \%)$ children. Wasting was observed in $22(6.12 \%)$ girls and $29(7.23 \%)$ boys, however this difference between sexes was not statistically significant $(\mathrm{p}=0.54) .75(9.87 \%)$ children were underweight of which eight $(1.05 \%)$ were of a severe degree. Among the girls, 31 $(8.63 \%)$ were underweight, while $44(10.97 \%)$ boys were underweight $(\mathrm{p}=0.28)$.

The highest prevalence of stunting (19 32.20\%) was observed among children whose mothers were educated up to primary level, while the lowest prevalence of stunting (23 $8.77 \%$ ) was seen in children whose mothers were graduates or above (Table 5). Of the 59 children whose mothers were educated up to primary level, $18(30.50 \%)$ had wasting while the lowest prevalence of six $(2.29 \%)$ was observed in children whose mothers were graduates or postgraduates $\left(\chi^{2}\right.$ for linear trends $=53.50, \mathrm{p}=0.000)$. The prevalence of underweight was least (nine $3.43 \%$ ) among children whose mothers were educated till graduation or beyond, while the highest prevalence (20 33.89\%) was observed among children whose mothers were educated till primary level $\left(\chi^{2}\right.$ for linear trends $=53.50, \mathrm{p}=0.000$ ).

The prevalence of stunting and underweight was higher among children whose mothers were housewives, while

Table 2

Comparison of mean weight of boys and girls

\begin{tabular}{|c|c|c|c|c|c|c|c|c|c|}
\hline \multirow[t]{2}{*}{ Age group } & \multicolumn{4}{|c|}{ Boys } & \multicolumn{4}{|c|}{ Girls } & \multirow[t]{2}{*}{$\mathrm{p}$ value } \\
\hline & $\begin{array}{c}\text { Number } \\
\text { examined }\end{array}$ & $\begin{array}{c}\text { Mean } \\
\text { weight }(\mathrm{Kg})\end{array}$ & SD & $\begin{array}{c}\text { Mean weight } \\
\text { (boys) WHO/ } \\
\text { NCHS standards }\end{array}$ & $\begin{array}{c}\text { Number } \\
\text { examined }\end{array}$ & $\begin{array}{c}\text { Mean } \\
\text { weight }(\mathrm{Kg})\end{array}$ & SD & $\begin{array}{c}\text { Mean weight } \\
\text { (girls) WHO/ } \\
\text { NCHS standards }\end{array}$ & \\
\hline $5+$ years & 27 & 18.4 & 2.66 & 18.6 & 25 & 18.0 & 4.24 & 18.1 & 0.42 \\
\hline $6+$ years & 67 & 19.5 & 3.50 & 21.3 & 66 & 19.3 & 3.80 & 21.0 & 0.80 \\
\hline $7+$ years & 63 & 22.4 & 4.46 & 24.0 & 68 & 22.3 & 5.45 & 22.2 & 0.94 \\
\hline $8+$ years & 81 & 24.8 & 4.7 & 26.4 & 46 & 24.6 & 5.83 & 26.3 & 0.98 \\
\hline $9+$ years & 79 & 27.6 & 6.25 & 28.8 & 61 & 28.1 & 6.02 & 30.8 & 0.48 \\
\hline $10+$ years & 53 & 30.7 & 6.17 & 33.6 & 51 & 31.7 & 7.16 & 32.6 & 0.43 \\
\hline $11+$ years & 31 & 34.5 & 5.59 & 36.9 & 42 & 35.7 & 4.24 & 37.6 & 0.35 \\
\hline
\end{tabular}


wasting was higher among children whose mothers were working. However, this difference was not statistically significant for any of the three nutritional indices, viz. stunting, wasting and underweight (Table 6).

Of the 426 children whose fathers were ORs, 73 (17.13\%) were stunted. The lowest prevalence of stunting 15 (9.49\%) was observed in the children whose fathers were officers. The prevalence of wasting was also lowest among the children of the officers, while the highest prevalence was observed among the children of other ranks. However this difference was not statistically significant. The prevalence of underweight was lowest in the children of officers and highest among children of other ranks. This trend was not statistically significant (Table 7).

Family size showed statistically significant association with the three nutritional indices of stunting, wasting and underweight. (Table 8). The prevalence was highest in families with more than 5 members.

\section{Discussion}

The present study showed a growth lag in the basic parameters of height and weight as compared to the reference standards laid down by $\mathrm{NCH} / \mathrm{WHO}$ amongst school children of Army School in Pune. Our findings are in agreement with that reported by other workers from India [8-11].

We analysed the prevalence of stunting, wasting and underweight as markers of undernutrition and found them to be present in $13.81 \%, 6.71 \%$ and $9.87 \%$ of children respectively. This was much lower than that reported by other workers who found mothers' education to be significantly related to all the three indices of malnutrition i.e. stunting, wasting and underweight. Data analysis of National Family Health Survey (NFHS) 1 [3], also showed that that mother's education has a strong independent effect on a child's nutritional status even after controlling for the potentially confounding effects of the 12 other demographic and socioeconomic variables [18]. Further improvement in nutritional status with maternal education has been reported by other workers [19-22]. Fathers' education was not significantly associated with any of the three indices of malnutrition.

Table 3

Comparison of mean height of boys and girls

\begin{tabular}{|c|c|c|c|c|c|c|c|c|c|}
\hline \multirow{2}{*}{$\begin{array}{l}\text { Age group } \\
\text { (years) }\end{array}$} & \multicolumn{4}{|c|}{ Boys } & \multicolumn{4}{|c|}{ Girls } & \multirow[t]{2}{*}{$\mathrm{p}$ value } \\
\hline & $\begin{array}{l}\text { Number } \\
\text { examined }\end{array}$ & $\begin{array}{c}\text { Mean } \\
\text { height (cms) }\end{array}$ & SD & $\begin{array}{c}\text { Mean height } \\
\text { (boys) WHO/ } \\
\text { NCHS standards }\end{array}$ & $\begin{array}{c}\text { Number } \\
\text { examined }\end{array}$ & $\begin{array}{c}\text { Mean } \\
\text { height }(\mathrm{cms})\end{array}$ & SD & $\begin{array}{l}\text { Mean height } \\
\text { (girls) WHO/ } \\
\text { NCHS standards }\end{array}$ & \\
\hline $5+\mathrm{yrs}$ & 27 & 107.3 & 4.07 & 108.9 & 25 & 105.1 & 9.4 & 107.9 & 0.44 \\
\hline $6+y r s$ & 67 & 113.1 & 6.03 & 116.1 & 66 & 112.8 & 5.79 & 115.4 & 0.77 \\
\hline $7+y r s$ & 63 & 118.1 & 7.40 & 122.6 & 68 & 117.9 & 7.08 & 120.6 & 0.92 \\
\hline $8+y r s$ & 81 & 123.5 & 8.2 & 128.1 & 46 & 122.2 & 8.6 & 127.4 & 0.40 \\
\hline $9+\mathrm{yrs}$ & 79 & 129.5 & 7.30 & 131.6 & 61 & 130.0 & 8.3 & 133.2 & 0.11 \\
\hline $10+y r s$ & 53 & 135.1 & 6.41 & 138.1 & 51 & 136.9 & 7.01 & 138.5 & 0.18 \\
\hline $11+\mathrm{yrs}$ & 31 & 142.1 & 8.69 & 143.4 & 42 & 143.1 & 9.63 & 144.0 & 0.65 \\
\hline
\end{tabular}

Table 4

Prevalence of stunting, wasting and underweight in study group according to WHO/NCHS standards

\begin{tabular}{|cccccccccc}
\hline & \multicolumn{3}{c}{ Stunted } & \multicolumn{4}{c}{ Wasted } \\
& Severe (\%) & Moderate $(\%)$ & Total $(\%)$ & Severe $(\%)$ & Moderate $(\%)$ & Total $(\%)$ & Severe $(\%)$ & Moderate $(\%)$ & Total $(\%)$
\end{tabular}

Table 5

Prevalence of stunting, wasting and underweight in study group according to maternal educational status

\begin{tabular}{|c|c|c|c|c|c|c|c|}
\hline Mothers education & n $(\%)$ & Stunted (\%) & OR & Wasted (\%) & OR & Underweight (\%) & OR \\
\hline Graduation and beyond & $262(100)$ & $23 \quad(8.77)$ & 1.00 & $6 \quad(2.29)$ & 1.00 & $(3.43)$ & 1.00 \\
\hline Intermediate & $163(100)$ & $17(10.42)$ & 1.21 & $(3.68)$ & 1.63 & $(7.98)$ & 2.55 \\
\hline High School & $180(100)$ & $21(11.66)$ & 1.37 & $9 \quad(5.00)$ & 2.25 & $12 \quad(6.66)$ & 1.65 \\
\hline Middle School & $96(100)$ & $25 \quad(26.04)$ & 3.66 & $12(12.5)$ & 6.10 & $21 \quad(21.85)$ & 8.65 \\
\hline Primary & $59(100)$ & $19(32.20)$ & 4.94 & $18(30.50)$ & 18.73 & $20 \quad(33.89)$ & 13.77 \\
\hline Total & $760(100)$ & $105(13.81)$ & & $51 \quad(6.71)$ & & $75 \quad(9.87)$ & \\
\hline$\chi^{2}$ for linear trends & & & 28.68 & & 48.70 & & 53.50 \\
\hline $\mathrm{p}$ value & & & 0.00 & & 0.00 & & 0.00 \\
\hline
\end{tabular}


Table 6

Prevalence of stunting, wasting and underweight in study group according to mothers' working status

\begin{tabular}{|c|c|c|c|c|c|c|c|}
\hline \multirow{2}{*}{ Mothers working status } & \multirow[t]{2}{*}{ n $(\%)$} & \multicolumn{2}{|c|}{ Stunted } & \multicolumn{2}{|c|}{ Wasted } & \multicolumn{2}{|c|}{ Underweight } \\
\hline & & Stunted $(\%)$ & Normal (\%) & Wasted (\%) & Normal (\%) & Underweight (\%) & Normal (\%) \\
\hline Working & $78(100)$ & $8 \quad(10.25)$ & $70 \quad(89.75)$ & $6(7.65)$ & $72(92.35)$ & $7 \quad(8.97)$ & $72(93.59)$ \\
\hline Housewives & $682(100)$ & $97 \quad(14.22)$ & $576 \quad(87.78)$ & $45(6.59)$ & $637(93.41)$ & $68 \quad(9.97)$ & $612(90.03)$ \\
\hline Total & 760 & 105 & 646 & 51 & 709 & 75 & 685 \\
\hline
\end{tabular}

Table 7

Prevalence of stunting, wasting, underweight with respect to socioeconomic status

\begin{tabular}{|c|c|c|c|c|c|c|c|}
\hline SE Status & n $(\%)$ & Total stunted $(\%)$ & OR & Total wasted $(\%)$ & OR & Total underweight (\%) & OR \\
\hline Officers & $158(100)$ & $15 \quad(9.49)$ & 1.00 & $8 \quad(5.06)$ & 1.00 & $11 \quad(6.96)$ & 1.00 \\
\hline JCOs & $176(100)$ & $17 \quad(9.65)$ & 1.13 & $12(6.81)$ & 1.37 & $17(9.65)$ & 1.43 \\
\hline OR & $426(100)$ & $73(17.13)$ & 2.18 & $31 \quad(7.27)$ & 1.47 & $47(11.02)$ & 1.62 \\
\hline Total & $760(100)$ & $105(13.81)$ & & $51 \quad(6.71)$ & & $75 \quad(9.87)$ & \\
\hline
\end{tabular}

Table 8

Prevalence of stunting, wasting and underweight with respect to family size

$\begin{array}{lcccccccc}\text { Family size (members) } & \mathrm{n}(\%) & \text { Total stunted }(\%) & \text { OR } & \text { Total wasted }(\%) & \text { OR } & \text { Total underweight }(\%) & \text { OR } \\ 3 & 159(100) & 19(11.95) & 1.00 & 05(3.14) & 1.00 & 12(7.55) & 1.00 \\ 4-5 & 534(100) & 31(5.81) & 0.45 & 30(5.62) & 1.83 & 45(8.42) & 1.13 \\ >5 & 67(100) & 55(82.05) & 33.77 & 16(23.88) & 9.66 & 18(26.87) & 4.50 \\ \text { Total } & 760(100) & 105(13.81) & & 51(6.71) & & 75(9.87)\end{array}$

The NFHS II observed a higher prevalence of these three indices of malnutrition in children of working mothers [3]. We could not establish any statistically significant relationship between the working status of women and presence of malnutrition in their children. This could be due to the fact that our study population was from a service background where better income, health care facilities and higher educational status of mothers were operative.

On comparing father's rank, taken as a marker for socio economic status, it was seen that children of ORs had higher prevalence of stunting, wasting and underweight as compared to the other two categories, though this difference was statistically significant only in case of stunting. Stunting reflects long-term malnutrition, and is influenced by parental attitudes and child care practices accumulating over a long period of time. Most army personnel stay away from their families for long periods and at such times, the families of officers belonging to relatively higher socioeconomic status generally stay in urban areas while those of ORs go back to their village. This differential in socio economic status, environmental conditions and maternal education operative over long periods of time could account for a higher prevalence of stunting amongst children of ORs.
On the other hand, underweight and wasting reflect an acute phenomenon and do not appear to be related to socioeconomic status of the family. Earlier studies have demonstrated relationship between the salaries of the father and one or more indices of malnutrition [21,22].

In the present study family size was significantly associated with all three indices of malnutrition. Similar results have been reported by Gopaldas et al [20]. NFHS 1 [3] survey also showed that children with three or more older siblings were more likely to suffer chronic malnutrition than children from smaller families.

This study shows that maternal educational status, socio-economic status and family size are important determinants of the nutritional status of the child. Efforts directed towards improvement of female literacy, socioeconomic status and restricting family size will have a positive impact of the nutritional status of school children.

\section{Conflicts of Interest}

None identified

Intellectual Contribution of Authors

Study Concept : Lt Col S Chaturvedi

Drafting \& Manuscript Revision : Maj R Mukerjee,

Lt Col S Chaturvedi, Col R Bhalwar

Statistical Analysis: Maj R Mukerjee

Study Supervision: Lt Col S Chaturvedi 


\section{References}

1. WHO. Child Health Research : A Foundation for Improving Child Health. Geneva: WHO, 2002.

2. Park K. Parks Textbook of Preventive and Social Medicine. $18^{\text {th }}$ ed. Jabalpur: Banarasidas Bhanot; 2005.

3. International Institute of Population Sciences. National Family Health Survey- 2, 1998-99. Mumbai, India:IIPS 2000.

4. International Food Policy Research Institute. Nutrition through out the lifecycle. $4^{\text {th }}$ Report on the World Nutrition Situation. Geneva : UN Administrative Committee on Coordination, 2000.

5. Jellife DB. The assessment of the nutritional status of the community, no 53.Geneva: World Health Organisation.

6. World Health Organization. Physical status: the use and interpretation of anthropometry. Technical report series 854 . Geneva: 1995.

7. World Health Organization. Measuring Change in Nutrition Status. Geneva: WHO 1983.

8. Agarwal DK, Agarwal KN, Upadhay SK, Mittal R, Prakash R, Rai S. Physical and sexual growth pattern of affluent Indian children from 5-18 years of age. Indian Pediatr 1992; 29 : 1202-84.

9. Bhasin SK, Singh S, Kapil U, Sood VP, Gaur DR. Height and Weight of 'well to do' school children in Haryana. Indian Pediatr 1990; 27: 1089-93.

10. Panda P, Benjamin AI, Singh S, Zachariah P. Health status of school children in Ludhiana city. Indian Journal of Community Medicine. 2000; 25 : 150-5.

11. Banerjee A. Height and weight patterns as indicators of growth among school children in an Air Force Station: A cross sectional study. MJAFI 2001; $57: 8-11$.

12. Anand K, Kant S, Kapoor SK. Nutritional status of adolescent school children in rural north India. Indian Pediatrics $1999 ; 36$ : $810-6$.

13. Umesh K, Sethi V. (Letter to editor). Indian Pediatrics 2004 ; 41:628.

14. Verma M, Chhatwal J, Kaur G. Prevalence of anemia among urban school children of Punjab. Indian Pediatrics 1998; 35 : 1181-6.

15. Raheela MA, Ali MM, Paola A, Underwood P. The nutritional status of school aged children in an urban squatter settlement in Pakistan. Pakistan Journal of Nutrition 2002 (cited 2005 Aug 12); 1: 121-3. Available from http//www.pjbs.org/pjnonline/ fin25.pdf.

16. Antonio P, Jose A, Maria, Damasceno A, Bueunen G. Anthropometric indicators of nutritional status; implications for fitness, activity, and health in school age children and adolescents from Maputo, Mozambique. American Journal of Clincal Nutrition, 2003; 77:952-9.

17. Shahabuddin AK, Talukder K, Talukder MK, Hassan M, Seal A, Rahman Q et al. Adolescent nutrition in a rural community in Bangladesh Indian Journal of Pediatrics 2000;67:93-8.

18. Mishra VK, Retherford RD. Women's Education can improve Child Nutrition in India. NFHS Bulletin 2000 ;15: 7-10.

19. Bishnoi P, Sehgal S, Kwatra A. Anthropometric measurements of preschool children as effected by socio-economic factors. Asian Pacific J Clinical Nutrition 2004;13S132.

20. Gopaldas T, Patel P, Bakshi M. Selected socio-economic, environmental, maternal, and child factors associated with the nutritional status of infants and toddlers. Food and Nutrition Bulletin 1998:10.

21. Ray SK, Biswas AK, Gupta SD, Mukerjee D, Kumar S, Biswas B, Joardar G. Rapid Assessment of nutritional status and dietary pattern in a municipal area. Indian Journal of Community Medicine 2000;7-10.

22. Shah SM, Selwyn BJ, Luby S, Merchant A, Bano R. Prevalence and correlates of stunting among children in rural Pakistan. Pediatrics International2003; $45: 49-53$.

23. Vella V, Tomkins A, Borghesi A, Migliori GB, Adriko BC, Crovatin E.Determinants of child nutrition and mortality in northwest Uganda. Bulletin of the World Health Organisation 1992; $70: 637-43$.

24. Li Y, Guo G, Shi A, Li Y, Anme T, Ushijima H. Prevalence and correlates of malnutrition among children in rural minority areas of China. Pediatr Int. 1999 ; 41:549-50.

\section{ATTENTION CME ORGANISERS}

All service hospitals/institutions organising CME will contribute to MJAFI fund as per the rates given below :-
(a) CME with less than 100 delegates
- $\quad$ Rs. $2500 /-$
(b) CME upto 300 delegates
- $\quad$ Rs. $5000 /-$
(c) CME with more than 300 delegates
- Rs. $10000 /-$ 